\title{
Causation between Agronomic Traits in Homozygous Soybean Lines
}

\author{
Mochammad Muchlish ADIE* and Ayda KRISNAWATI
}

Indonesian Legume and Tuber Crops Research Institute, Malang, East Java, Indonesia

('Corresponding author's e-mail: mm_adie@yahoo.com)

Received: 2 March 2020, Revised: 14 March 2021, Accepted: 21 March 2021

\begin{abstract}
Seed yield in soybean is associated with other yield components. The objective of the study was to investigate the pattern of relationship between seed yield and yield components in soybean. Agronomic characters and seed yield of 147 soybean homozygous lines (HL) and 3 check cultivars (Dega 1, Detap 1, and Anjasmoro) were evaluated in Banyuwangi (East Java, Indonesia) from April to July 2018. The field experiment was conducted in a randomized complete block design with 2 replications. After threshing, the HLs were grouped into large seed size (> $14.00 \mathrm{~g} / 100 \mathrm{seeds})$ and medium seed size (10 - $14 \mathrm{~g} / 100$ seeds). The causation and inter-relationship between yield components and seed yield were quantified using path analysis. Based on the seed size, a total of $150 \mathrm{HLs}$ was grouped into 97 lines and 53 lines of large and medium seed size, respectively. The correlation analysis showed a similar pattern between groups of large and medium seed size. The seed yield in both groups was highly determined by the characters of the number of filled pods, number of nodes, number of branches, plant height, and wet biomass. The results of path analysis revealed that plant age, particularly the length of the generative phase, was an important factor affecting seed yield in large seed soybean lines. The length of the generative phase determining the soybean yield in this study can be suggested to be used as selection criteria to obtain high yielding and large seed size variety.
\end{abstract}

Keywords: Correlation, $\mathrm{F}_{6}$ population, Path analysis, Yield component

\section{Introduction}

Improvement programs for the genetic potential of soybean variety in Indonesia still emphasize maximizing the yield per unit area [1]. National soybean productivity was $1.48 \mathrm{t} / \mathrm{ha}$ [2], and the targeted yield productivity in the research area was $2.50-3.0 \mathrm{t} / \mathrm{ha}$ [3-5]. Most of the soybean varieties in Indonesia were developed from the crossing of two parents and then followed by the selection in each generation. The selected lines in the $\mathrm{F}_{6}$ generation were categorized as HL. The selection in a homozygous generation $\left(\mathrm{F}_{6}\right)$ of soybean is mostly based on yield as an indicator of selection.

Seed yield in soybean is a complex character, composed of and influenced by various yield components that are interrelated between each other. Seed yield is an inherited quantitative trait and is strongly influenced by environmental fluctuations. Board et al. [6] classified the yield components into 3 groups, namely (i) primary components that affect the final yield (the number and the seed size), (ii) secondary components that affect the number of seeds (number of seeds per pod and number of pods per plant), and (iii) the tertiary component of yield that affects the number of pods (the number of fertile nodes, number of pods per node, and number of branches).

The relationship between yields and yield components in soybeans has become the object of study in improving yield per unit area [7-9]. Sudaric et al. [10] examined the performance of 14 soybean cultivars over 5 years (1996 - 2000) and obtained the seed weight and the number of seeds per plant as an efficient indirect selection for seed yield in soybean. Machikowa and Laosuwan [11] evaluated the relationship of early maturing soybean and found that the number of pods and the number of branches per 
http://wjst.wu.ac.th

plant are important characters in soybean for indirect selection. A study which examined the relationship between yield and yield components, by Ghodrati et al. [12], obtained the highest correlation value of yield with total dry matter $\left(\mathrm{r}=0.82^{* *}\right)$, followed by the seed filling period $\left(\mathrm{r}=0.65^{* *}\right)$ and the harvest index $\left(\mathrm{r}=0.64^{* *}\right)$. Further analysis using multiple regression of stepwise and path analysis showed that dry matter was the most important character for the improvement of yield. Valencia-Ramírez and Liggareto-Moreno [13] reported that seed yield correlated with number of pods $\left(\mathrm{r}=0.81^{* *}\right)$, number of nodes $\left(\mathrm{r}=0.67^{* *}\right)$, and number of seeds/pod $\left(\mathrm{r}=0.44^{* *}\right)$, but was negatively correlated with seed weight $(\mathrm{r}$ $\left.=-0.44^{* *}\right)$. Additional evaluation using path analysis showed that the number of pods had a strong direct effect on seed yield (0.62), followed by the number of nodes (0.260). A study on vegetable soybean in Northeast China recommended using the number of seeds per plant, 2-seeded pod width, 2-seeded pod length, weight of 100 fresh seeds, and plant height as selection indicators for a higher fresh pod yield [14].

The various patterns of the relationship between agronomic traits and soybean yields indicate that the performance of the agronomic traits in soybeans is quantitative, determined by the characteristics of the location and the genetic material used. The yield of seeds in soybeans is reported to be a quantitative trait and controlled by genes with low heritability [15]. Accordingly, the design of breeding programs to increase seed yield will be more efficient if it starts with studying the relationship between agronomic traits and, also, the relationship with seed yield [16,17].

Many studies suggest that, if there is a correlation between agronomic characters, it can be considered as an indirect selection criterion [17,18]. Rao et al. [19] showed that yield is a function of several yield components, consisting of the character of the number of pods, the number of seeds per pod, plant height, the number of nodes, seed size, and even include size of plant populations. This indicates that the relationship between yields and quantitative traits builds complex patterns; hence, the technique of analysis is required to explain the pattern of relationships, and also the mechanism of relationships between quantitative traits and seed yield. In this study, further information on the relationship among agronomic characters is important for establishing selection criteria in the soybean breeding program for high yield.

Therefore, the objective of the study was to investigate the pattern of relationship between seed yield and yield components in soybean.

\section{Materials and methods}

The field experiment was conducted during the dry season 2018 (March to June) at Gambiran, Banyuwangi (East Java, Indonesia). The research area was located at the coordinates of $8^{\circ} 22^{\prime} 44.4^{\prime \prime}$ South Latitude and $114^{\circ} 8^{\prime} 45.6^{\prime \prime}$ East Longitude, $168 \mathrm{~m}$ above sea level, with C2 (Oldeman) climate type, rainfall of $4,300 \mathrm{~mm} /$ year, minimum temperature of $23{ }^{\circ} \mathrm{C}$ and maximum temperature of $30{ }^{\circ} \mathrm{C}, 82.5 \%$ relative humidity, and a soil type of Entisol [20].

\section{Research materials}

The materials consisted of $147 \mathrm{~F}_{6}$ soybean HLs, including 3 check cultivars (Dega 1, Detap 1, and Anjasmoro). The homozygous pure lines were derived from the selection of $\mathrm{F}_{5}$ segregating populations using the mass selection method based on seed yield.

\section{Field study}

A randomized complete block design was used, with 2 replications. The experiment was conducted in the lowlands after rice planting and without soil tillage. Each line was planted in a plot size of $1.2 \times 4.0$ $\mathrm{m}^{2}$, with plant spacing of $40 \times 15 \mathrm{~cm}^{2}, 2$ plants per hill. Fertilizers were applied after sowing at the rate of $50 \mathrm{~kg} / \mathrm{ha}$ Urea, $100 \mathrm{~kg} / \mathrm{ha} \mathrm{SP36}$, and $75 \mathrm{~kg} / \mathrm{ha} \mathrm{KCl} \mathrm{[21].} \mathrm{Starting} 10$ days after planting, pests and diseases were intensively controlled by applying insecticides at 10-day intervals. Weeding was applied at 3, 6, and 9 weeks after planting. Soybean was harvested at $\mathrm{R}_{8}$ (full maturity), or when $95 \%$ of its leaves had turned yellow. After threshing, the genotypes were grouped into large seed size ( $>14.00 \mathrm{~g} / 100$ seeds) and medium seed size (10 - $14 \mathrm{~g} / 100$ seeds) based on the seed size classification in Indonesia [22,23]. 
http://wjst.wu.ac.th

\section{Data analysis}

The data of all characters and groups of large and medium seed size genotypes were subjected to one-way analysis of variance (ANOVA) using SAS software version 9.1.3 [24]. For each seed size group, descriptive statistics were estimated, in terms of average, minimum, and maximum values. The pattern of causation between characters was estimated by using correlation and path analysis [25].

\section{Results and discussion}

In Indonesia, soybean is mainly used as raw material for the tempeh industry; hence, seed size is one of the considerations of user preferences in choosing soybean varieties. Soybean seed sizes in Indonesia are grouped into large seed size ( $>14 \mathrm{~g} / 100$ seeds), medium seed size (10 - $14 \mathrm{~g} / 100$ seeds), and small seed size $(<10 \mathrm{~g} / 100$ seeds) [16]; meanwhile, plant age in soybean is categorized as early maturity ( $<80$ days), medium maturity ( 80 - 90 days), and late maturity ( $>90$ days) [26].

The results of the analysis of variance showed significant variation in the seed yield and yield components of 150 soybean genotypes (Table 1). The high coefficient of variation (CV) indicated much variability in data [27] among HLs, particularly in the characters of the number of branches, in the number of empty pods, and in wet and dry biomass.

Table 1 Analysis of variance for agronomic characters of homozygous soybean lines.

\begin{tabular}{|c|c|c|c|c|c|c|c|c|c|c|}
\hline \multirow{3}{*}{ No } & \multirow{3}{*}{ Characters } & \multicolumn{9}{|c|}{ Mean square } \\
\hline & & \multicolumn{3}{|c|}{150 lines } & \multicolumn{3}{|c|}{ Large seed-size lines (97 lines) } & \multicolumn{3}{|c|}{ Medium seed-size lines (53 lines) } \\
\hline & & Replication & Line & $\begin{array}{l}\text { CV } \\
(\%)\end{array}$ & Replication & Line & $\begin{array}{l}\text { CV } \\
(\%)\end{array}$ & Replication & Line & $\begin{array}{l}\text { CV } \\
(\%)\end{array}$ \\
\hline 1 & HS & $0.4977^{\mathrm{ns}}$ & $9.6010^{* *}$ & 12.91 & $9.0432^{* *}$ & $1.0733^{\mathrm{ns}}$ & 14.48 & $0.1000^{\text {ns }}$ & $0.1427^{\mathrm{ns}}$ & 21.07 \\
\hline 2 & FD & $1.4700^{\mathrm{ns}}$ & $6.0036^{* *}$ & 2.48 & $5.5821^{* *}$ & $1.6701^{\mathrm{ns}}$ & 2.34 & $4.9676^{* *}$ & $2.0850^{\mathrm{ns}}$ & 2.10 \\
\hline 3 & MD & $5.8800^{\mathrm{ns}}$ & $12.3954^{* *}$ & 2.07 & $12.3489^{* *}$ & $7.8402^{\mathrm{ns}}$ & 2.14 & $5.2626^{* *}$ & $0.0849^{\mathrm{ns}}$ & 2.70 \\
\hline 4 & $\mathrm{G} / \mathrm{V}$ & $0.0031^{\mathrm{ns}}$ & $0.0805^{* *}$ & 2.18 & $0.0715^{* *}$ & $0.0009^{\mathrm{ns}}$ & 2.06 & $9.4691^{* *}$ & $0.0849^{\mathrm{ns}}$ & 1.93 \\
\hline 5 & $\mathrm{PH}$ & $7.2075^{\mathrm{ns}}$ & $149.3198^{* *}$ & 16.64 & $123.2076^{* *}$ & $0.3096^{\mathrm{ns}}$ & 12.33 & $0.0901^{* *}$ & $0.0019^{\mathrm{ns}}$ & 2.45 \\
\hline 6 & NB & $0.0833^{\mathrm{ns}}$ & $1.1358^{* *}$ & 22.36 & $1.1529^{* *}$ & $0.0544^{\mathrm{ns}}$ & 22.81 & $200.1922^{*}$ & $27.7647^{\mathrm{ns}}$ & 22.32 \\
\hline 7 & $\mathrm{NN}$ & $5.6252^{\mathrm{ns}}$ & $22.9262^{* *}$ & 17.08 & $22.2755^{* *}$ & $8.0425^{\mathrm{ns}}$ & 16.33 & $0.9780^{*}$ & $0.0288^{\mathrm{ns}}$ & 21.81 \\
\hline 8 & FP & $952.4077^{* *}$ & $244.3301^{* *}$ & 16.89 & $247.5296^{* *}$ & $558.0450^{\mathrm{ns}}$ & 16.42 & $23.0957^{*}$ & $0.0235^{\mathrm{ns}}$ & 18.35 \\
\hline 9 & EP & $1.4076^{* *}$ & $0.1173^{* *}$ & 22.94 & $0.1243^{\mathrm{ns}}$ & $1.4306^{* *}$ & 23.68 & $234.9375^{*}$ & $398.3985^{\text {ns }}$ & 17.79 \\
\hline 10 & WB & $2.3620^{\mathrm{ns}}$ & $3.5484^{* *}$ & 29.32 & $3.2809^{* *}$ & $6.1353^{\mathrm{ns}}$ & 27.44 & $0.8319^{\mathrm{ns}}$ & $0.0460^{\mathrm{ns}}$ & 6.98 \\
\hline 11 & DB & $0.2075^{\mathrm{ns}}$ & $1.2251^{* *}$ & 22.84 & $1.0006^{* *}$ & $0.0768^{\mathrm{ns}}$ & 22.56 & $3.8905^{\mathrm{ns}}$ & $0.5857^{\mathrm{ns}}$ & 31.77 \\
\hline 12 & HI & $0.9070^{\mathrm{ns}}$ & $0.3646^{* *}$ & 18.85 & $0.4411^{\mathrm{ns}}$ & $2.3079^{* *}$ & 18.99 & $1.5461^{*}$ & $0.1532^{\mathrm{ns}}$ & 23.94 \\
\hline 13 & $\mathrm{~S} / \mathrm{P}$ & $10.5618^{\mathrm{ns}}$ & $16.1762^{* *}$ & 18.96 & $17.9433^{* *}$ & $5.6748^{\mathrm{ns}}$ & 18.21 & $0.2297^{\mathrm{ns}}$ & $0.2031^{\mathrm{ns}}$ & 17.96 \\
\hline
\end{tabular}

${ }^{* *}=$ significant at $1 \%$ probability level $(\mathrm{P}<0.01),{ }^{*}=$ significant at $5 \%$ probability level $(\mathrm{P}<0.05)$, ns $=$ not significant, $\mathrm{CV}=$ coefficient of variation, $\mathrm{HS}=100$ seed weight $(\mathrm{g}), \mathrm{FD}=$ days to flowering, $\mathrm{MD}=$ days to maturity, $\mathrm{G} / \mathrm{V}=$ generative/vegetative ratio, $\mathrm{PH}=$ plant height $(\mathrm{cm}), \mathrm{NB}=$ number of branches $/$ plant, $\mathrm{NN}=$ number of nodes/plant, $\mathrm{FP}=$ number of filled pods/plant, $\mathrm{EP}=$ number of empty pods/plant, $\mathrm{WB}=$ wet biomass $(\mathrm{t} / \mathrm{ha}), \mathrm{DB}=$ dry biomass $(\mathrm{t} / \mathrm{ha}), \mathrm{HI}=$ harvest index, $\mathrm{S} / \mathrm{P}=$ weight of seed/plant $(\mathrm{g})$.

In the group of HLs, the average seed size of 97 lines was $15.84 \mathrm{~g}$ per 100 seeds, with a range between 14.00 - 30.94 g per 100 seeds. Meanwhile, in the group of medium seeded HLs, a total of 53 lines had an average seed size of $13.09 \mathrm{~g}$ per 100 seeds, with a range between 10.74 - $13.99 \mathrm{~g}$ (Table 2). The performance of plant age characters (days to flowering, days to maturity, and generative/vegetative ratio) was comparable between the group of large and medium seed size lines. A similar pattern between those groups also showed in the characters of plant height, the number of branches, and harvest index.

The number of nodes, the number of filled pods, the wet biomass weight, and the dry biomass weight in the group of medium seed size HLs were higher than those in the group of large seed size lines. 
http://wjst.wu.ac.th

The number of empty pods and the weight of seeds per plant in the group of large seed size HLs were higher when compared to the group of medium seed size lines (Table 2).

Table 2 Descriptive statistics of seed yield and related characters of soybean HLs for each seed size group.

\begin{tabular}{lccccccccc}
\hline \multirow{2}{*}{ No } & \multirow{2}{*}{ Characters } & \multicolumn{4}{c}{ Large seed size } & \multicolumn{4}{c}{ Medium seed size } \\
\cline { 2 - 10 } & & Mean & Std & Min & Max & Mean & Std & Min & Max \\
\hline 1 & HS & 15.84 & 2.12 & 14.04 & 30.94 & 13.09 & 0.63 & 10.74 & 13.99 \\
2 & FD & 32.46 & 1.66 & 30.00 & 36.00 & 33.44 & 1.69 & 30.00 & 36.00 \\
3 & MD & 83.01 & 2.47 & 79.00 & 87.50 & 84.58 & 2.13 & 80.00 & 87.50 \\
4 & G/V & 1.57 & 0.08 & 1.40 & 1.75 & 1.53 & 0.09 & 1.39 & 1.75 \\
5 & PH & 49.52 & 7.84 & 36.13 & 82.25 & 49.92 & 9.81 & 36.38 & 102.00 \\
6 & NB & 3.12 & 0.75 & 1.13 & 5.63 & 3.46 & 0.68 & 1.63 & 4.88 \\
7 & NN & 18.10 & 3.33 & 8.88 & 26.25 & 19.15 & 3.33 & 12.13 & 30.50 \\
8 & FP & 61.48 & 11.12 & 22.73 & 90.75 & 62.98 & 10.64 & 40.50 & 97.88 \\
9 & EP & 1.37 & 0.70 & 0.13 & 3.63 & 1.16 & 0.57 & 0.25 & 3.00 \\
10 & WB & 4.85 & 1.28 & 2.11 & 7.99 & 5.26 & 1.36 & 1.69 & 10.14 \\
11 & DB & 2.82 & 0.70 & 1.24 & 4.55 & 3.12 & 0.86 & 1.21 & 6.15 \\
12 & HI & 0.34 & 0.16 & 0.20 & 1.88 & 0.34 & 0.08 & 0.22 & 0.84 \\
13 & S/P & 15.98 & 2.99 & 8.51 & 23.87 & 14.90 & 2.37 & 8.93 & 21.25 \\
\hline
\end{tabular}

Std $=$ standard deviation, $\mathrm{Min}=$ minimum value, $\mathrm{Max}=$ maximum value, $\mathrm{HS}=100$ seed weight $(\mathrm{g}), \mathrm{FD}=$ days to flowering, $\mathrm{MD}=$ days to maturity, $\mathrm{G} / \mathrm{V}=$ generative/vegetative ratio, $\mathrm{PH}=$ plant height $(\mathrm{cm}), \mathrm{NB}=$ number of branches/plant, $\mathrm{NN}=$ number of nodes/plant, $\mathrm{FP}=$ number of filled pods/plant, $\mathrm{EP}=$ number of empty pods/plant, $\mathrm{WB}=$ wet biomass $(\mathrm{t} / \mathrm{ha}), \mathrm{DB}=$ dry biomass $(\mathrm{t} / \mathrm{ha}), \mathrm{HI}=$ harvest index, $\mathrm{S} / \mathrm{P}=$ weight of seed $/$ plant $(\mathrm{g})$.

The relationship between yield and yield components was investigated by using correlation and path analysis on each group of large and medium seeded HLs. In the group of large seeded lines, the seed yield was strongly determined by the number of filled pods $\left(\mathrm{r}=0.804^{* *}\right)$, followed by the number of nodes $(\mathrm{r}=$ $\left.0.669^{* *}\right)$, plant height $\left(\mathrm{r}=0.515^{* *}\right)$, the number of branches $\left(\mathrm{r}=0.443^{* *}\right)$, and wet biomass $\left(\mathrm{r}=0.287^{* *}\right)$. The plant age characters, which consist of the days to flowering and days to maturity, were positively correlated with the seed yield $\left(r=0.344^{* *}\right.$ and $r=0.382^{* *}$, respectively). However, the generative and vegetative ratio $(\mathrm{G} / \mathrm{V})$ was negatively correlated with the seed yield $\left(\mathrm{r}=-0.222^{*}\right)$ (Table 3$)$. Research by Mahbub et al. [28] in Bangladesh found that the characters of days to flowering and the days to maturity have important roles in soybean yield, as indicated by their correlation values $\left(\mathrm{r}=0.98^{* *}\right.$ and $\mathrm{r}=0.91^{* *}$, respectively). Meanwhile, Sulistyo et al. [29] found the days to flowering, plant height, and number of fertile nodes had a positive correlation with seed yield. In canola, it was reported that seed yield was negatively correlated with the duration of the flowering period, and positively correlated with the duration of the generative phase [30]. Observing the causality patterns in large seeded lines, it can be seen that the determinant of high yield is the number of filled pods, which is strongly determined by the character of the number of nodes. Meanwhile, the number of nodes is determined by the number of branches. These 3 characters form a highly strong interdependence pattern in determining the seed yield in soybean.

Path analysis for the group of large seeded lines (Table 4) showed that the wet biomass weight, dry biomass weight, and harvest index had the highest direct effect on the seed yield compared to other characters. However, those 3 characters tend to cancel each other out through their indirect effects. For example, the direct effect of the wet biomass weight on seed yield was 4.827 , but the indirect effect on seed yield through the dry biomass weight was -3.636. A similar pattern was also shown in the direct effect of the days to flowering to seed yield (1.335); however, the indirect effect on seed yield through the days to flowering was -0.422 . The direct effect of the days to maturity on yield was -0.527 , and the indirect effect through the days to flowering was 1.068. Interestingly, the direct effect of G/V on yield was 0.658 , but it was weakened by the indirect effect through the character of days to flowering $(-1.117)$. 
http://wjst.wu.ac.th

The significance of the relationship for plant age characters in large seeded soybean lines is that the seed yield will be achieved optimally when the generative period is long enough.

In the current study, the number of seeds and 100 seed weight (seed size) are the main characters of yield components in soybean. The number of seeds is determined by the number of pods and the number of seeds per pod. The character of 100 seed weight has a relatively high direct effect on yield (0.477), but it is weakened by its indirect effect through the character of days to flowering (-0.207) (Table 4). Genetic analysis, carried out by Bhor et al. [31], on soybean suggested that 100 seed weight could be used as selection criteria for soybean in the early generation $\left(\mathrm{F}_{3}\right)$. The direct effect of the number of filled pods on the yield of seeds was 0.407 , and the indirect effect through the days to flowering was 0.499 , through the character of the number of nodes was -0.015 , and through the character of the $\mathrm{G} / \mathrm{V}$ was -0.197 . When it correlates with the correlation value, then the number of pods has the highest correlation value, and the direct effect is also relatively high. Thus, the character of the number of filled pods can be considered as a determinant of high yield on large seeded soybean as long as the G/V ratio is quite high. Large seeded soybean lines require a longer generative phase to optimize the process of seed filling. In the field pea (Pisum sativum L.), the number of pods was also reported as an important character determining the seed yield [32].

In the group of HLs with medium seed size, the number of filled pods had the highest correlation value $\left(\mathrm{r}=0.758^{* *}\right)$ to seed yield, followed by the number of nodes $\left(\mathrm{r}=0.597^{* *}\right)$, plant height $\left(\mathrm{r}=0.431^{* *}\right)$, and the number of branches $\left(r=0.360^{* *}\right)$. The number of filled pods was strongly determined by the number of nodes $\left(\mathrm{r}=0.767^{* *}\right)$, the number of nodes also showed a very strong correlation with the number of branches $\left(\mathrm{r}=0.752^{* *}\right)$, and the number of nodes was determined by the plant height character $\left(\mathrm{r}=0.404^{* *}\right)$ (Table 5). The plant age characters in the group of medium seeded soybean lines, which consisted of days to flowering, days to maturity, and the ratio of the generative with vegetative phase $(\mathrm{G} / \mathrm{V})$, did not affect the seed yield character. Harvest index also had no effect on seed yield, but the weight of wet and dry biomass affected the seed yield $\left(r=0.366^{* *}\right.$ and $r=0.418^{* *}$, respectively). The interrelation patterns of the 4 characters, namely the number of pods, the number of nodes, the number of branches, and plant height on the seed yield showed a similar pattern as the group of large seeded lines. The results are in line with previous studies. Characterization of 27 soybean genotypes by Hakim [33] revealed that high yielded soybean was characterized by a relatively high plant and a large number of pods. Furthermore, Krisnawati and Adie [9] suggested the plant height could be considered as a selection indicator for high yield in soybean. In mungbean, plant height has also become one of the high yield determinants [34].

Table 3 Correlation coefficients among seed yield and related characters of large seeded soybean lines.

\begin{tabular}{|c|c|c|c|c|c|c|c|c|c|c|c|c|}
\hline Character & HS & FD & MD & G/V & $\mathbf{P H}$ & NB & $\mathbf{N N}$ & FP & EP & WB & DB & HI \\
\hline $\mathrm{S} / \mathrm{P}$ & $-0.105^{\mathrm{ns}}$ & $0.344^{* *}$ & $0.382^{* *}$ & $-0.222^{*}$ & $0.515^{* *}$ & $0.443^{* *}$ & $0.669^{* *}$ & $0.804^{* *}$ & $0.038^{\mathrm{ns}}$ & $0.287^{* *}$ & $0.247^{\mathrm{ns}}$ & $0.006^{\mathrm{ns}}$ \\
\hline HS & 1 & $-0.155^{\mathrm{ns}}$ & $-0.044^{\mathrm{ns}}$ & $0.192^{\mathrm{ns}}$ & $-0.032^{\mathrm{ns}}$ & $-0.339^{* *}$ & $-0.304^{* *}$ & $-0.321^{* *}$ & $-0.015^{\mathrm{ns}}$ & $-0.14^{\mathrm{ns}}$ & $-0.111^{\mathrm{ns}}$ & $-0.055^{\mathrm{ns}}$ \\
\hline FD & & 1 & $0.80^{* *}$ & $-0.837^{* *}$ & $0.356^{* *}$ & $0.280^{* *}$ & $0.399^{* *}$ & 0.374 & $-0.129^{\mathrm{ns}}$ & $0.260^{* *}$ & $0.279^{* *}$ & $-0.129^{\mathrm{ns}}$ \\
\hline MD & & & 1 & $-0.372^{* *}$ & $0.365^{* *}$ & $0.315^{* *}$ & $0.445^{* *}$ & $0.339^{* *}$ & $-0.083^{\mathrm{ns}}$ & $0.410^{* *}$ & $0.389^{* *}$ & $-0.266^{* *}$ \\
\hline $\mathrm{G} / \mathrm{V}$ & & & & 1 & $-0.229^{*}$ & $-0.191^{\mathrm{ns}}$ & $-0.264^{* *}$ & $-0.299^{* *}$ & $0.127^{\mathrm{ns}}$ & $-0.026^{\mathrm{ns}}$ & $-0.06^{\mathrm{ns}}$ & $-0.029^{\mathrm{ns}}$ \\
\hline $\mathrm{PH}$ & & & & & 1 & $0.120^{\mathrm{ns}}$ & $0.480^{* *}$ & $0.449^{* *}$ & $-0.200^{*}$ & $0.377^{* *}$ & $0.368^{* *}$ & $0.062^{\mathrm{ns}}$ \\
\hline NB & & & & & & 1 & $0.741^{* *}$ & $0.536^{* *}$ & $0.146^{\mathrm{ns}}$ & $0.138^{\mathrm{ns}}$ & $0.136^{\mathrm{ns}}$ & $-0.061^{\mathrm{ns}}$ \\
\hline $\mathrm{NN}$ & & & & & & & 1 & $0.771^{* *}$ & $0.038^{\mathrm{ns}}$ & $0.300^{* *}$ & $0.269^{* *}$ & $-0.057^{\mathrm{ns}}$ \\
\hline $\mathrm{FP}$ & & & & & & & & 1 & $0.032^{\mathrm{ns}}$ & $0.267^{* *}$ & $0.227^{*}$ & $0.003^{\mathrm{ns}}$ \\
\hline EP & & & & & & & & & 1 & $-0.067^{\mathrm{ns}}$ & $-0.039^{\mathrm{ns}}$ & $0.067^{\mathrm{ns}}$ \\
\hline WB & & & & & & & & & & 1 & $0.866^{* *}$ & $-0.221^{*}$ \\
\hline DB & & & & & & & & & & & 1 & $0.082^{\mathrm{ns}}$ \\
\hline $\mathrm{HI}$ & & & & & & & & & & & & 1 \\
\hline
\end{tabular}

$\mathrm{S} / \mathrm{P}=$ weight of seed/plant $(\mathrm{g})$, HS $=100$ seed weight $(\mathrm{g}), \mathrm{FD}=$ days to flowering, $\mathrm{MD}=$ days to maturity, G/V = generative/vegetative ratio, $\mathrm{PH}=$ plant height $(\mathrm{cm}), \mathrm{NB}=$ number of branches/plant, $\mathrm{NN}=$ number of nodes $/$ plant, $\mathrm{FP}=$ number of filled pods/plant, $\mathrm{EP}=$ number of empty pods/plant, $\mathrm{WB}=$ wet biomass $(\mathrm{t} / \mathrm{ha}), \mathrm{DB}=$ dry biomass $(\mathrm{t} / \mathrm{ha}), \mathrm{HI}=\mathrm{harvest}$ index, $\mathrm{ns}=\mathrm{not}$ significant, ${ }^{*}=$ significant at $\mathrm{P} \leq 0.05,{ }^{* *}=$ significant at $\mathrm{P} \leq 0.01$. 
http://wjst.wu.ac.th

Table 4 Direct (bold) and indirect effects of yield related characters on seed yield of large seeded soybean lines.

\begin{tabular}{|c|c|c|c|c|c|c|c|c|c|c|c|c|c|}
\hline Character & HS & FD & MD & G/V & $\mathbf{P H}$ & NB & $\mathbf{N N}$ & FP & EP & WB & DB & HI & $\mathbf{r}$ \\
\hline HS & 0.477 & -0.207 & 0.023 & 0.126 & 0.006 & -0.112 & 0.006 & -0.131 & -0.001 & -0.676 & 0.466 & -0.084 & $-0.105^{\mathrm{ns}}$ \\
\hline FD & -0.074 & 1.335 & -0.422 & -0.551 & -0.062 & 0.092 & -0.008 & 0.152 & -0.007 & 1.255 & -1.172 & -0.196 & $0.344^{* *}$ \\
\hline MD & -0.021 & 1.068 & $-\mathbf{0 . 5 2 7}$ & -0.245 & -0.063 & 0.104 & -0.008 & 0.138 & -0.004 & 1.979 & -1.633 & -0.404 & \\
\hline $\mathrm{G} / \mathrm{V}$ & 0.092 & -1.117 & 0.196 & 0.658 & 0.040 & -0.063 & 0.005 & -0.122 & 0.007 & -0.126 & 0.252 & -0.044 & $-0.222^{*}$ \\
\hline $\mathrm{PH}$ & -0.015 & 0.475 & -0.192 & -0.151 & -0.173 & 0.039 & -0.009 & 0.183 & -0.010 & 1.820 & -1.545 & 0.094 & $0.515^{* *}$ \\
\hline NB & -0.162 & 0.374 & -0.166 & -0.126 & -0.021 & 0.329 & -0.014 & 0.218 & 0.008 & 0.666 & -0.571 & -0.093 & $0.443^{* *}$ \\
\hline $\mathrm{NN}$ & -0.145 & 0.533 & -0.235 & -0.174 & -0.083 & 0.244 & -0.019 & 0.314 & 0.002 & 1.448 & -1.130 & -0.087 & $0.669^{* *}$ \\
\hline EP & -0.007 & -0.172 & 0.044 & 0.084 & 0.035 & 0.048 & -0.001 & 0.013 & 0.052 & -0.323 & 0.164 & 0.102 & $0.038^{\mathrm{ns}}$ \\
\hline WB & -0.067 & -0.347 & -0.216 & -0.017 & -0.065 & 0.045 & -0.006 & 0.109 & -0.003 & 4.827 & -3.636 & -0.336 & $0.287^{* *}$ \\
\hline DB & -0.053 & 0.372 & -0.205 & -0.039 & -0.064 & 0.045 & -0.005 & 0.092 & -0.002 & 4.180 & -4.199 & 0.125 & $0.247^{\mathrm{ns}}$ \\
\hline $\mathrm{HI}$ & -0.026 & -0.172 & 0.140 & -0.019 & -0.011 & -0.020 & 0.001 & 0.001 & 0.003 & -1.067 & -0.345 & 1.519 & $0.006^{\mathrm{ns}}$ \\
\hline
\end{tabular}

$\mathrm{HS}=100$ seed weight $(\mathrm{g}), \mathrm{FD}=$ days to flowering, $\mathrm{MD}=$ days to maturity, $\mathrm{G} / \mathrm{V}=$ generative/vegetative ratio, $\mathrm{PH}=$ plant height $(\mathrm{cm}), \mathrm{NB}=$ number of branches/plant, $\mathrm{NN}=$ number of nodes/plant, $\mathrm{FP}=$ number of filled pods/plant, $\mathrm{EP}=$ number of empty pods/plant, $\mathrm{WB}=$ wet biomass $(\mathrm{t} / \mathrm{ha}), \mathrm{DB}=\operatorname{dry}$ biomass $(\mathrm{t} / \mathrm{ha}), \mathrm{HI}=\mathrm{harvest}$ index, $\mathrm{r}=$ coefficient of correlation.

Table 5 Correlation coefficients for seed yield and related characters of medium seeded soybean lines.

\begin{tabular}{|c|c|c|c|c|c|c|c|c|c|c|c|c|}
\hline Character & HS & FD & MD & G/V & $\mathbf{P H}$ & NB & $\mathbf{N N}$ & FP & EP & WB & DB & HI \\
\hline $\mathrm{S} / \mathrm{P}$ & $-0.118^{\mathrm{ns}}$ & $0.173^{\mathrm{ns}}$ & $0.124^{\mathrm{ns}}$ & $-0.147^{\mathrm{ns}}$ & $0.431^{* *}$ & $0.360^{* *}$ & $0.597^{* *}$ & $0.758^{* *}$ & $0.192^{\mathrm{ns}}$ & $0.366^{* *}$ & $0.418^{* *}$ & $-0.066^{\mathrm{ns}}$ \\
\hline HS & 1 & $-0.097^{\mathrm{ns}}$ & $-0.119^{\mathrm{ns}}$ & $0.085^{\mathrm{ns}}$ & $-0.239^{\mathrm{ns}}$ & $-0.07^{\mathrm{ns}}$ & $-0.294^{*}$ & $-0.390^{* *}$ & $0.089^{\mathrm{ns}}$ & -0.252 & $-0.245^{\mathrm{ns}}$ & $0.200^{\mathrm{ns}}$ \\
\hline FD & & 1 & $0.706^{* *}$ & $-0.843^{* *}$ & $0.344^{*}$ & $0.198^{\text {ns }}$ & $0.309^{*}$ & $0.125^{\mathrm{ns}}$ & $-0.076^{\mathrm{ns}}$ & 0.259 & $0.368^{* *}$ & $-0.053^{\mathrm{ns}}$ \\
\hline MD & & & 1 & $-0.248^{\mathrm{ns}}$ & $0.301^{* *}$ & $0.244^{\mathrm{ns}}$ & $0.399^{* *}$ & $0.203^{\mathrm{ns}}$ & $0.307^{* *}$ & $0.336^{* *}$ & $0.463^{* *}$ & $-0.030^{\mathrm{ns}}$ \\
\hline $\mathrm{G} / \mathrm{V}$ & & & & 1 & $-0.267^{*}$ & $-0.145^{\mathrm{ns}}$ & $-0.173^{\mathrm{ns}}$ & $-0.059^{\mathrm{ns}}$ & $0.345^{* *}$ & $-0.073^{\mathrm{ns}}$ & $-0.136^{\mathrm{ns}}$ & $0.016^{\mathrm{ns}}$ \\
\hline $\mathrm{PH}$ & & & & & 1 & $-0.001^{\mathrm{ns}}$ & $0.404^{* *}$ & $0.312^{*}$ & $-0.037^{\mathrm{ns}}$ & $0.352^{* *}$ & $0.399^{* *}$ & $-0.051^{\mathrm{ns}}$ \\
\hline NB & & & & & & 1 & $0.752^{* *}$ & 0.540 & $0.209^{\mathrm{ns}}$ & $0.099^{\mathrm{ns}}$ & $0.001^{\mathrm{ns}}$ & $0.093^{\mathrm{ns}}$ \\
\hline $\mathrm{NN}$ & & & & & & & 1 & $0.767^{* *}$ & $0.217^{\mathrm{ns}}$ & $0.333^{* *}$ & $0.339^{* *}$ & $-0.148^{\mathrm{ns}}$ \\
\hline FP & & & & & & & & 1 & $0.238^{\mathrm{ns}}$ & $0.262^{\mathrm{ns}}$ & $0.332^{*}$ & $-0.092^{\mathrm{ns}}$ \\
\hline EP & & & & & & & & & 1 & $0.098^{\mathrm{ns}}$ & $0.189^{\mathrm{ns}}$ & $-0.230^{\mathrm{ns}}$ \\
\hline WB & & & & & & & & & & 1 & $0.875^{* *}$ & $-0.356^{* *}$ \\
\hline DB & & & & & & & & & & & 1 & $-0.210^{\mathrm{ns}}$ \\
\hline HI & & & & & & & & & & & & 1 \\
\hline
\end{tabular}

$\mathrm{S} / \mathrm{P}=$ weight of seed/plant $(\mathrm{g}), \mathrm{HS}=100$ seed weight $(\mathrm{g}), \mathrm{FD}=$ days to flowering, $\mathrm{MD}=$ days to maturity, G/V = generative/vegetative ratio, $\mathrm{PH}=$ plant height $(\mathrm{cm}), \mathrm{NB}=$ number of branches/plant, $\mathrm{NN}=$ number of nodes/plant, FP $=$ number of filled pods/plant, EP = number of empty pods/plant, WB = wet biomass $(\mathrm{t} / \mathrm{ha}), \mathrm{DB}=\mathrm{dry}$ biomass $(\mathrm{t} / \mathrm{ha})$, $\mathrm{HI}=$ harvest index, $\mathrm{ns}=$ not significant, ${ }^{*}=$ significant at $\mathrm{P} \leq 0.05,{ }^{* *}=$ significant at $\mathrm{P} \leq 0.01$.

Path analysis revealed that the number of filled pods in the group of medium seeded soybean lines was crucial, which was indicated by a high direct effect value $(0.772)$ and the coefficient of correlation which was almost equal $\left(\mathrm{r}=0.758^{* *}\right)$ (Table 6). As stated by Singh and Chaudhary [25], if the correlation coefficient between a causal factor and the effect is almost equal to its direct effect, then correlation explains the true relationship; hence, the number of filled pods could be used as an effective selection index for high yield. Similarly, Kuswantoro et al. [35] also found the number of filled pods as a determinant of high yield in soybean. However, another study found the true relationship between the pod numbers per plant with seed yield [36]. 
http://wjst.wu.ac.th

The direct effects of the days to flowering and days to maturity were 0.353 and -0.383 , respectively. However, both of them weaken each other, and the direct effect of G/V was very small. When the role of plant age characters was compared between large and medium seeded groups, it was revealed that they played different roles. The role of plant age character, including the ratio between the lengths of the generative and vegetative phases, was significant in large sized soybean lines, but in soybean lines with medium sized seeds, the role of plant age character did not really determine seed yield.

Table 6 Direct (bold) and indirect effects of yield related characters on seed yield of medium seeded soybean lines.

\begin{tabular}{cccccccccccccccc}
\hline Character & HS & FD & MD & G/V & PH & NB & NN & FP & EP & WB & DB & HI & r \\
\hline HS & $\mathbf{0 . 2 4 4}$ & -0.034 & 0.046 & 0.009 & -0.045 & 0.005 & -0.010 & -0.301 & 0.009 & -0.049 & -0.005 & 0.013 & $-0.118^{\text {ns }}$ \\
FD & -0.024 & $\mathbf{0 . 3 5 3}$ & -0.270 & -0.090 & 0.064 & -0.014 & 0.010 & 0.097 & -0.008 & 0.051 & 0.007 & -0.003 & $0.173^{\text {ns }}$ \\
MD & -0.029 & 0.249 & $-\mathbf{0 . 3 8 3}$ & -0.027 & 0.056 & -0.018 & 0.013 & 0.157 & 0.031 & 0.066 & 0.009 & -0.002 & $0.124^{\text {ns }}$ \\
G/V & 0.021 & -0.298 & 0.095 & $\mathbf{0 . 1 0 7}$ & -0.050 & 0.010 & -0.006 & -0.046 & 0.035 & -0.014 & -0.003 & 0.001 & $-0.147^{\text {ns }}$ \\
PH & -0.058 & 0.121 & -0.115 & -0.029 & $\mathbf{0 . 1 8 7}$ & 0.000 & 0.013 & 0.241 & -0.004 & 0.069 & 0.008 & -0.003 & $0.43^{* *}$ \\
NB & -0.017 & 0.070 & -0.093 & -0.016 & -0.000 & $-\mathbf{0 . 0 7 2}$ & 0.025 & 0.417 & 0.021 & 0.019 & 0.000 & 0.006 & $0.360^{* *}$ \\
NN & -0.072 & 0.109 & -0.153 & -0.019 & 0.076 & -0.054 & $\mathbf{0 . 0 3 3}$ & 0.592 & 0.022 & 0.065 & 0.007 & -0.010 & $0.597^{* *}$ \\
FP & -0.095 & 0.044 & -0.078 & -0.006 & 0.058 & -0.039 & 0.025 & $\mathbf{0 . 7 7 2}$ & 0.024 & 0.051 & 0.007 & -0.006 & $0.758^{* *}$ \\
EP & 0.022 & -0.027 & -0.118 & 0.037 & -0.007 & -0.015 & 0.007 & 0.184 & $\mathbf{0 . 1 0 1}$ & 0.019 & 0.004 & -0.015 & $0.192^{\text {ns }}$ \\
WB & -0.061 & 0.091 & -0.129 & -0.008 & 0.066 & -0.007 & 0.011 & 0.202 & 0.010 & $\mathbf{0 . 1 9 6}$ & 0.018 & -0.023 & $0.366^{* *}$ \\
DB & -0.060 & 0.130 & -0.177 & -0.015 & 0.075 & -0.000 & 0.011 & 0.256 & 0.019 & 0.172 & $\mathbf{0 . 0 2 0}$ & -0.014 & $0.418^{* *}$ \\
HI & 0.049 & -0.019 & 0.011 & 0.002 & -0.010 & 0.007 & -0.005 & -0.071 & -0.023 & -0.070 & -0.004 & $\mathbf{0 . 0 6 6}$ & $-0.066^{\text {ns }}$ \\
\hline
\end{tabular}

$\mathrm{HS}=100$ seed weight $(\mathrm{g}), \mathrm{FD}=$ days to flowering, $\mathrm{MD}=$ days to maturity, $\mathrm{G} / \mathrm{V}=$ generative/vegetative ratio, $\mathrm{PH}=$ plant height $(\mathrm{cm}), \mathrm{NB}=$ number of branches/plant, $\mathrm{NN}=$ number of nodes/plant, $\mathrm{FP}=$ number of filled pods/plant, $\mathrm{EP}=$ number of empty pods/plant, $\mathrm{WB}=$ wet biomass $(\mathrm{t} / \mathrm{ha}), \mathrm{DB}=$ dry biomass $(\mathrm{t} / \mathrm{ha}), \mathrm{HI}=$ harvest index, $\mathrm{r}=$ coefficient of correlation.

\section{Conclusions}

Seed yield in soybean HLs is arranged and determined by various agronomic characters that are interconnected between each other. The characters of the number of filled pods, the number of nodes, the number of branches, plant height, and wet biomass are the main components of seed yield on large, as well as medium, seeded groups. The plant age character affects seed yield only in large seeded soybean lines when it is combined with the large G/V ratio; meanwhile, it does not affect the yield in medium seeded soybean lines. Therefore, the selection process to obtain high-yielding soybean could be based on the important traits found in this study.

\section{Acknowledgements}

This research was supported by the Indonesian Agency for Agricultural Research and Development (IAARD), Ministry of Agriculture, RI. The authors sincerely thank Mr. Mispan from Genteng Research Station for his help during the field research.

\section{References}

[1] A Hasbianto, S Hartati and CK Weebadde. Opportunities, challenges, and strategies to increase soybean production in Indonesia. Jurnal Informasi Teknologi Pertanian 2020; 1, 72-91.

[2] Ministry of Republic of Indonesia. Outlook of food crops: Soybean. Pusdatin, Kementan, 2020, p. 66.

[3] A Krisnawati and MM Adie. Variability of soybean genotypes based on high yield and seed size supporting industrial raw material. In: Proceedings of the $2^{\text {nd }}$ International Conference on Sustainable Innovation. Springer, Singapore, 2017, p. 101.

[4] MM Adie and A Krisnawati. Identification of soybean genotypes adaptive to tropical area and suitable for industry. IOP Conf. Ser. Earth Environ. Sci. 2018; 102, 012045. 
http://wjst.wu.ac.th

[5] MM Adie, A Krisnawati and R Iswanto. Agronomic performance of soybean genotypes in lowland paddy fields under zero-tillage condition. Biosaintifika 2020; 12, 140-6.

[6] JE Board, MS Kang and BG Harville. Path analyses identify indirect selection criteria for yield of late-planted soybean. Crop Sci. 1997; 37, 879-84.

[7] MFA Malik, M Ashraf, AS Qureshi and A Ghafoor. Assessment of genetic variability, correlation and path analysis for yield and its components in soybean. Pak. J. Bot. 2007; 39, 405-13.

[8] M Arshad, N Ali and A Ghafoor. Character correlation and path coefficient in soybean Glycine max (L.) Merrill. Pak. J. Bot. 2006; 38, 121-30.

[9] A Krisnawati and MM Adie. The relationship between morphological component with seed yield character in soybean. Bul. Palawija 2016; 14, 49-54.

[10] A Sudaric, V Marija and T Duvnjak. Quantitative genetic analysis of yield components and grain yield for soybean cultivars. Poljoprivreda (Osijek) 2003; 8, 11-5.

[11] T Machikowa and P Laosuwan. Path coefficient analysis for yield of early maturing soybean. Songklanakarin J. Sci. Technol. 2001; 33, 365-8.

[12] GR Ghodrati, R Sekhavat, SH Mahmoodinezhadedezfully and A Gholami. Evaluation of correlations and path analysis of components seed yield in soybean. Int. J. Agric. Res. Rev. 2013; 3, 795-800.

[13] RA Valencia-Ramírez and GA Ligarreto-Moreno. Phenotypic correlation and path analysis for yield in soybean (Glycine max (L.) Merril). Acta Agronómica 2012; 61, 322-32.

[14] YS Li, M Du, QY Zhang, M Hashemi, XB Liu and SJ Hebert. Correlation and path coefficient analysis for yield components of vegetable soybean in Northeast China. Legume Res. 2013; 36, 2848.

[15] JW Burton. Quantitative genetics: Results relevant to soybean breeding. Agronomy 1987; 16, 211 47.

[16] MFA Malik, M Ashraf, AS Qureshi and A Ghafoor. Utilization of diverse germplasm for soybean yield improvement. Asian J. Plant Sci. 2006; 5, 663-7.

[17] M Oz, A Karasu, AT Goksoy and ZM Turan. Interrelationships of agronomical characteristics in soybean (Glycine max) grown in different environments. Int. J. Agric. Biol. 2009; 11, 85-8.

[18] AK Sarawgi, NK Rastogi and DK Soni. Correlation and path analysis in rice accessions from Madhya Pradesh. Field Crops Res. 1997; 52, 161-7.

[19] MSS Rao, AS Bhagsari and AI Mohamed. Fresh green seed yield and seed nutritional traits of vegetable soybean genotypes. Crop Sci. 2002; 42, 1950-8.

[20] Balitkabi. Balai penelitian tanaman aneka kacang dan umbi. Booklet, Indonesian Legume and Tuber Crops Research Institute, 2017, p. 10.

[21] IAARD. Technology of soybean production. Booklet, Indonesian Agency for Agricultural Research and Development, 2017, p. 19.

[22] A Krisnawati and MM Adie. Selection of soybean genotypes by seed size and its prospects for industrial raw material in Indonesia. Procedia Food Sci. 2015; 3, 355-63.

[23] A Krisnawati and MM Adie. The leaflet shape variation from several soybean genotypes in Indonesia. Biodiversitas 2017; 18, 359-64.

[24] SAS Institute. SAS/STAT® 9.1.3 user's guide. SAS Institute, Cary, NC, 2007.

[25] RK Singh and BD Chaudhary. Biometrical methods in quantitative genetic analysis. Kalyani Publisher, New Delhi, India, 1979, p. 388.

[26] MM Adie MM and A Krisnawati. Clustering of high-yielding and early maturing soybean genotypes. In: Proceedings of the $2^{\text {nd }}$ International Conference on Sustainable Innovation. Springer, Singapore. 2017, p. 13.

[27] S Chanda, Y Kanke, M Dalen, J Hoy and B Tubana. Coefficient of variation from vegetation index for sugarcane population and stalk evaluation. Agrosyst. Geosci. Environ. 2018; 1, 180016.

[28] MM Mahbub and BJ Shirazy. Evaluation of genetic diversity in different genotypes of soybean (Glycine max (L.) Merrill). Amer. J. Plant Biol. 2016; 1, 24-9. 
http://wjst.wu.ac.th

[29] A Sulistyo, Purwantoro and KP Sari. Correlation, path analysis and heritability estimation for agronomic traits contribute to yield on soybean. IOP Conf. Ser. Earth Environ. Sci. 2018; 102, 012034.

[30] G Yantai, KN Harker, HR Kutcher, RH Gulden, B Irvine, WE May and JT O'Donovan. Canola seed yield and phenological responses to plant density. Can. J. Plant Sci. 2016; 96, 151-9.

[31] TJ Bhor, VP Chimote and MP Deshmukh. Genetic analysis of yield and yield components in soybean (Glycine max (L.) Merrill). Indian J. Agric. Res. 2014; 48, 446-52.

[32] B Kumar, A Kumar, AK Singh and GR Lavanya. Selection strategy for seed yield and maturity in field pea (Pisum sativum L. arvense). Afr. J. Agric. Res. 2013; 8, 5411-5.

[33] L Hakim. Correlation among characters and path analyses between agronomic traits with grain yield on soybean \{Glycine $\max$ (L.) Merrill\}. Berita Biologi 2011; 10, 709-20.

[34] RT Hapsari. Estimation of genetic variability and correlation among early maturity mungbean yield components. Bul. Plasma Nutfah 2014; 20, 51-8.

[35] H Kuswantoro, L Ujianto, A Sulistyo and RT Hapsari. Yield and yield components of soybean lines in two locations. J. Agron. Indonesia 2016; 44, 26-32.

[36] B Enideg, S Alamerew, A Tesfaye and J Barnabas. Character correlation and path analysis for yield and yield related components in soybean (Glycine max L.) genotypes. Int. J. Sci. Appl. Res. 2016; 3, 97-104. 